\title{
STRATEGI PENGEMBANGAN MANAJEMEN SUMBER DAYA MANUSIA BAGI GENERASI MILLENIAL
}

\author{
Armansyahfudin \\ Institut Pesantren KH Abdul Chalim Mojokerto \\ Email: armansyahfudin0@gmail.com
}

\begin{abstract}
Abstrak
Sumber daya manusia merupakan anugrah yang tidak ternilai harganya. Dengan meningkatkan kemampuan sumber daya manusia, maka akan memberikan dampak yang besar bagi kemajuan baik di bidang sosial, politik, ekonomi, bahkan teknologi. Tujuan dalam penulisan ini adalah untuk memberikan strategi yang bisa di gunakan dalam membangun generasi manusia terutama generasi millenial agar bisa bersaing di lingkungan masyarakat dimasa mendatang. Generasi milenial adalah generasi yang tumbuh dan berkembang dalam dunia yang pekembangan teknologi dan pengetahuan yang sangat pesat. Generasi millenial merupakan potensi sumber daya manusia yang apabila dimanfaatkan secara optimal akan memberikan dampak perubahan yang sangat besar. Metode yang di gunakan adalah studi pustaka. Strategi-strategi pengembangan yang efisien dan efektif bagi generasi millenial dalam meningkatkan potensi-potensi yang berada di dalam diri mereka bisa di mulai sejak mereka masuk di bangku sekolah.
\end{abstract}

Kata kunci: Strategi Pengembangan , Manajemen Sumber Daya Manusia, Generasi Millenial.

\begin{abstract}
Human resources are a priceless gift. By increasing the ability of human resources, it will have a major impact on progress in the social, political, economic, and even technological fields. The purpose of this paper is to provide a strategy that can be used in building buman generations, especially millennial, so that they can compete in the future community. Millennial generation is the generation that grows and develops in a world that is developing technology and knowledge very rapidly. Millennial generation is a potential human resource which, when utilized optimally, will have a profound change effect. The method used is literature study. Development strategies that are efficient and effective for millennial in increasing the potential within themselves can begin when they enter school.
\end{abstract}

Key words: Development Strategy, Human Resource Management, Millennial Generation. 


\section{Pendahuluan}

sumber daya manusia (SDM) adalah "kekuatan yang berasal dari dalam diri masusia. Kekuatan ini disebut manpower yang diartikan keahlian atau skill yang dimiliki oleh setiap manusia. ${ }^{1}$ SDM adalah kemampuan yang berada di dalam diri manusia untuk menciptakan statusnya sebagai makhluk sosial yang bisa beradaptasi dan menyesuaikan serta sanggup mengatur dirinya sendiri serta seluruh potensi yang terkandung di alam menuju tercapainya kesejahteraan kehidupan dalam tatanan yang seimbang dan berkelanjutan. ${ }^{2}$

Kualitas sumber daya manusia akan selalu terkait dengan tuntutan kerja yang profesional ${ }^{3}$. Sehingga hasil

\footnotetext{
1 Inggar Ariani Karendra, "Pengaruh
} Kualitas Sumber Daya Manusia Terhadap Perkembangan Usaha Pada Kpri Pertaguma Kota Madiun," Equilibrium: Jurnal Ilmiah Ekonomi Dan Pembelajarannya 2, No. 2 (1 Juli 2014): 190 , Https://Doi.Org/10.25273/Equilibrium.V2i2 .646.

2 Ida Kintamani Dh, "Analisis Sumber Daya Manusia Pendidikan Tinggi," Jurnal Pendidikan Dan Kebudayaan 17, No. 4 (1 Juli 2011): 406 , Https://Doi.Org/10.24832/Jpnk.V17i4.37.

3 Muhammad Anas Ma`arif dan Muhammad Husnur Rofiq, "Pola Pengembangan Kurikulum Pendidikan Pesantren Berkarakter: Studi Pondok Pesantren Nurul Ummah Mojokerto," TADRIS: Jurnal Pendidikan Islam 13, no. 1 (7 September 2018): 1-16, https://doi.org/10.19105/tjpi.v13i1.1635. dari pekerjaan, merupakan poin penting untuk melihat sejauh mana ia profesional dengan profesi yang digelutinya. Oleh karena bukan rahasia umum lagi jika kualitas sumber daya manusia yang tinggi akan menciptakan orang-orang yang profesional. Sumber daya manusia dapat dibilang sama dengan tenaga kerja. Dalam KBBI, sumber daya manusia dinyatakan sebagai faktor produksi yang digunakan dalam aktivitas ekonomi untuk memperoleh barang dan jasa serta menyalurkannya. ${ }^{4}$

Joko menyatakan bahwa pengaturan kemampuan sumber daya manusia (SDM) diawali dari perencanaan, pengorganisasian, pengembangan dan evaluasi dengan penjelasan sebagai berikut: Perencanaan, yaitu merencanakan kemampuan SDM dengan berpatokan pada visi dan misi organisasi, serta diartikan dalam strategi fungsional untuk mengetahui panutan kemampuan yang harus dipenuhi. (2) Pengorganisasi kemampuan SDM, yaitu meletakkan tempat-tempat yang

4 Sri Ningsih, "Perlakuan Akuntansi Sumber Daya Manusia: Assets Sekaligus Investor Bagi Perusahaan," Journal Of Accounting And Investment 2, No. 1 (16 Desember 2015): 14. 
sesuai bagi kompetensi inti dan pendukung. Dimaksudkan agar organisasi bisa dengan mudah mengerjakan upaya pengembangan kemampuan. (3) Pengembangan kemampuan, yaitu diawali dengan penilaian terhadap kemampuan yang sudah dimiliki SDM dan dicomparasikan dengan perencanaan kemampuan. (4) Evaluasi terhadap kemampuan, yaitu untuk mengetahui sudah seberapa jauh pekerjaan yang dilakukan telah mencapai sasaran yang telah ditentukan. ${ }^{5}$

Oleh karenanya, Kualitas sumber daya manusia merupakan kemampuan sumber daya manusia untuk melakukan tugas dan tanggungjawab yang diamanahkan kepada dirinya dengan bekal keterampilan yang diperoleh melalui pendidikan, pelatihan dan pengalaman yang cukup. ${ }^{6}$ Sumber daya manusia

\footnotetext{
5 Ahmad Azmy, "Pengembangan Kompetensi Sumber Daya Manusia Untuk Mencapai Career Ready Professional Di Universitas Tanri Abeng," Binus Business Review 6, No. 2 (31 Agustus 2015): 228, Https://Doi.Org/10.21512/Bbr.V6i2.971.

6 Wiwin Sukiati Dan Yuli Surya Fauzia Pertami, "Analisis Kualitas Sumber Daya Manusia Bagian Akuntansi Dalam Pemahaman Terhadap Laporan Keuangan Pada Bumd Kota Bandung," Jurnal Riset Akuntansi Dan Keuangan 5, No. 1 (21 April 2017): 1371 , Https://Doi.Org/10.17509/Jrak.V5i1.6738.
}

merupakan satu- satunya sumber daya yang mempunyai akal perasaan, keinginan, keterampilan, pengetahuan, dorongan, daya, dan karya (rasio, rasa, dan karsa). ${ }^{7}$ Peningkatan sumber daya manusia merupakan sesuatu yang mutlak adanya. Eksistensinya merupakan sebuah keharusan sebagai sebagai suatu konsekuensi untuk membekali manusia dalam menjawab tantangan kehidupan di segala aspek. ${ }^{8}$

Strategi pengembangan sumber daya manusia merupakan suatu keharusan untuk menjawab tantangan yang akan dihadapi dimasa depan. Semakin kompleksnya permasalahan yang dihadapi sekarang ini menuntut kita agar bisa bersaing di segala bidang di sektor kehidupan. Kehadiran sumber daya manusia yang berkualitas dan kompeten merupakan harapan yang sangat besar untuk bisa memberikan andil besar dalam persaingan baik itu persaingan dalam

${ }^{7}$ Kadek Hengki Primayana, "Manajemen Sumber Daya Manusia Dalam Peningkatan Mutu Pendidikan Di Perguruan Tinggi," Jurnal Penjaminan Mutu 1, No. 2 (9 Agustus 2016): 8, Https://Doi.Org/10.25078/Jpm.V1i2.45.

8 M. Tahir Dan Ananiah Ananiah, "Manajemen Sumber Daya Manusia Di Sekolah-Sekolah Unggulan Islam Kota Samarinda," Fenomena 4, No. 1 (1 Juni 2012): 49, Https:/ /Doi.Org/10.21093/Fj.V4i1.256. 
ilmu pengetahuan, ekonomi bahkan teknologi.

Oleh karenanya memberikan strategi pengembangan yang efektif dan efisien terutama bagi generasi millenial sekarang ini merupakan suatu yang harus dilakukan. Mengingat generasi mellenial adalah generasi yang tumbuh dan berkembang dalam era teknologi yang sangat maju sekarang ini. Sehingga menuntut mereka untuk bisa bersaing agar mereka bisa eksis di dalam kehidupannya.

Generasi milenial merupakan aset yang tidak ternilai harganya yang apa bila kita bisa mengolahnya dengan baik maka akan memberikan dampak yang sangat besar bagi perubahan di masa depan, tapi apabila kita tidak memperdulikannya maka akan menjadi bumerang dimasa yang akan datang. Oleh sebab itu maka sudah menjadi keharusan agar kita bisa memaksimalkan generasi millenial ini agar bisa eksis dalam kehidupannya, maka kita harus mempersiapkan strategi pengembangan yang sangat berguna bagi mereka untuk menghadapi kehidupannya, baik itu di bidang ekonomi, pengetahuan, sosial, budaya,politik, dan teknologi.

\section{Kajian Teori}

Manajemen Sumber Daya Manusia

Manajemen sumber daya manusia (MSDM) merupakan bagian dari konsep besar ilmu manajemen. Berbicara tentang manajemen, maka akan sampai pada pemahaman organisasi. Dan Organisasi sendiri mempunyai sumber daya yang digunakan dalam pencapaian tujuan. Sumber daya tersebut dalam manajemen dikenal dengan istilah $6 \mathrm{M}$, yakni man, material, method, money, machine dan market. Di antara 6M tersebut, yang kiranya menjadi sumber daya yang paling penting dan komplek adalah men, atau sumber daya manusia. ${ }^{9}$

Manajemen sumber daya manusia merupakan salah satu bidang dari manajemen umum yang meliputi segi-segi perencanaan, pengorganisasian, pelaksanaan dan pengendalian. Sumber daya manusia dianggap semakin penting peranannya dalam pencapaian tujuan, maka

\footnotetext{
9 Mustaqim Mustaqim, "Analisis Manajemen Pemasaran Jasa Lembaga Pendidikan Islam: Pondok Pesantren Amtsilati Darul Falah Bangsri Jepara," Nadwa 12, No. 1 (20 Juni 2018): 403, Https://Doi.Org/10.21580/Nw.2018.12.1.24 65.
} 
berbagai pengalaman dan hasil penelitian dalam bidang sumber daya manusia dikumpulkan secara sistematis dalam apa yang disebut dengan manajemen sumber daya manusia. Pemanfaatan sumber daya manusia, adalah proses kegiatan pemimpin yang bermaksud mempekerjakan pegawai yang memberi prestasi cukup dan tidak mempekerjakan pegawai yang tidak bermanfaat. $^{10}$

Faktor sumber daya manusia merupakan faktor penting yang mempengaruhi kualitas organisasi. Widarsono dalam penelitiannya menyampaikan bahwa Sumber Daya Manusia (SDM) mempunyai peran penting yang sangat besar yang mempengaruhi keberhasilan perusahaan dalam menghadapi pasar global dan kompetisi. $^{11}$ Oleh karenanya pengelolaan SDM menjadi bagian yang sangat penting dari tugas manajemen organisasi. Seberapa baik

\footnotetext{
${ }^{10}$ M. Nazar Almasri, "Manajemen Sumber Daya Manusia: Imlementasi Dalam Pendidikan Islam," Kutubkhanab 19, No. 2 (23 Januari 2017): 1.

11 Walid Fajar Antariksa, "Analisis Manajemen Sumber Daya Manusia Di Sekolah Dasar Islam Terpadu," Madrasah: Jurnal Pendidikan Dan Pembelajaran Dasar 10, No. 1 (29 Desember 2017): 48, Https://Doi.Org/10.18860/Madrasah.V10i1. 5096.
}

SDM dikelola akan menentukan kesuksesan organisasi di masa akan datang. Sebaliknya, jika SDM tidak dikelola dengan baik, efektivitas tidak akan tercapai. ${ }^{12}$

\section{Generasi Millenial}

Generasi millenial atau generasi $\mathrm{Y}$ adalah generasi yang lahir diantara tahun 1981 sampai dengan 2003. Mereka adalah generasi yang cenderung lebih fleksibel dan menyukai kebebasan serta hal yang sifatnya personal. Sikap kerja mereka pun berbeda dengan generasi-generasi sebelumnya, salah satunya adalah generasi millenial memiliki preferensi yang kuat terkait dengan struktur organisasi dan sistem yang mendukungnya. ${ }^{13}$

Para peneliti sosial sering mengelompokkan mereka sebagai generasi yang lahir di antara tahun 1980-an sampai 2000-an atau bisa dikatakan bahwa mereka adalah pemuda yang saat ini berusia 17-37

Rozalinda Rozalinda,
"Konsep
Manajemen Sumber Daya
Manusia :
Implementasi Pada Industri Perbankan
Syariah," Al-Masraf: Jurnal Lembaga Kenangan
Dan Perbankan 1, No. 1 (1 Juni 2016): 109.
13 Satria Aji Setiawan Dan Nova
Puspitasari, "Preferensi Struktur Organisasi
Bagi Generasi Millenial," Jurnal Borneo
Administrator 14, No. 2 (25 Juli 2018): 101,
Https://Doi.Org/10.24258/Jba.V14i2.336.


tahun (RumahMillenials.com, 2017).

Generasi ini identik dengan teknologi, khususnya internet dan media sosial. Menurut penelitian Pew Research Center (2010), generasi milenial tidak bisa dilepaskan dari penggunaan teknologi, terutama internet, karena hal itu sudah menjadi kebutuhan pokok mereka dan kebanyakan dari mereka memiliki media sosial. ${ }^{14}$

Menurut Lyons, Generasi Y atau sering disebut generasi millenial yaitu generasi yang memiliki karakteristik yang setiap individunya berbeda karena tergantung di tempat mana ia dibesarkan, ekonomi keluarganya, kehidupan sosialnya, dan memiliki pola komunikas yang terbuka, pengguna sosial media yang fanatik dan kehidupan generasi $Y$ sangat dipengaruhi oleh teknologi dengan kata lain generasi $\mathrm{Y}$ adalah generasi yang lahir dan tumbuh disaat kemajuan teknologi informasi yang cepat. Generasi Y yang kemudian disebut generasi millenial sangat menyukai keterbukaan yang artinya perilaku komunikasi generasi millenial

14 Noveliyati Sabani, "Generasi Millenial Dan Absurditas Debat Kusir Virtual," Informasi 48, No. 1 (25 Juli 2018): 96, Https://Doi.Org/10.21831/Informasi.V48i1. 18078. identik dengan verbal, frontal, dan konfrontatif. $^{15}$

Dari beberapa pengertian generasi millenial diatas bisa di simpulkan bahwa generasi millenial atau generasi $\mathrm{Y}$ adalah suatu generasi yang memiliki kemampuan pribadi atau personal di atas rata-rata karena mereka paham dengan pekerjaan yang mereka geluti dan mereka lebih percaya diri dengan kemampuan yang mereka miliki, karena generasi millenial merupakan generasi yang hidup di jaman teknologi dan informasi yang berkembang pesat sehingga mereka dengan mudah dalam menyelesaikan pekerjaan yang mereka lakukan, di bantu dengan kemampuan berkomunikasi yang baik dari personality mereka.

\section{Metode}

Metode yang di gunakan dalam Penelitian ini adalah dengan cara library research/studi pustaka. Studi pustaka merupakan suatu metode yang menggunakanan sumber bacaan

\footnotetext{
15 Ahmad Andry Ahmad Andry, "Lesbian, Gay , Bisexual Dan Transgender Penyembuhan Dan Upaya Membentuk Kepribadian Islami Di Era Generasi Millenial Melalui Psikoterapi Islam," Fikrotuna 8, No. 2 (31 Desember 2018): 936, Https://Doi.Org/10.32806/Jf.V8i2.3253.
} 
relevan yang telah ada, yang sesuai dengan topik yang akan dibahas dan diperluas pemahamannya ${ }^{16}$. Buku atau artikel jurnal yang sesuai dan terikat dengan topik yang disajikan digunakan sebagai bahan bacaan, untuk memahami dengan cermat isi dari hasil pikiran tokoh yang hasilnya menjadi materi bahasan dalam tulisan ini ataupun bermacam macam tanggapan dan kajian yang krusial dan penting atas hasil pemikiran tersebut. Tulisan ini dikembangkan dari bermacammacam sumber bacaan yang disajikan, termasuk mengaukan argumen atau komentar kritis, khususnya pada bagian simpulan.

\section{Pembahasan}

Untuk meningkatkan sumber daya manusia agar menjadi lebih efektif dan efisien maka di perlukan langkah-langkah yang sesuai agar tujuan yang ingin dicapai dapat terpenuhi. Strategi pengembangan pengembangan sumber daya manusia adalah langkah-langkah yang dilakukan agar setiap individu bisa diberikan metode yang sesuai dengan

\footnotetext{
16 Mestika Zed, Metode penelitian kepustakaan, Ed. 2 (Jakarta: Yayasan Obor Indonesia, 2008).
}

kemampuan yang dimilikinya, sehingga ia bisa menerima apa yang diberikan kepadanya untuk dijadikan sebagai bekal agar bisa bersaing di dalam segala sektor di bidang kehidupan. Didalam manajemen sumber daya manusia terdapat strategi yang bisa digunakan untuk meningkatkan pengembangan kompetensi atau kemampuan bagi setiap individu agar bisa eksis dan bersaing yang di kenal dengan Training And Development Human Resource.

$$
\text { meningkatkan kemampuan }
$$
kompetensi yang dimiliki oleh setiap orang agar menjadi lebih berkembang dan maju sesuai dengan kebutuhan yang diinginkan. Macam-macam program latihan dan pengembangannya sebagai berikut:

\section{Training responsibility}

Dalam

meningkatkan kompetensi yang dimiliki setiap individu latihan bertanggungjawab merupakan sesuatu yang wajib dilakukan. Menurut George Bernard Shaw orang yang dapat bertanggungjawab terhadap tindakannya dan mempertanggungjawabkan perbuatannya hanyalah orang yang 
mengambil keputusan dan bertindak tanpa tekanan dari pihak manapun atau secara bebas.

Latihan agar memiliki rasa tanggung jawab harus dilakukan semenjak mereka bergabung dalam suatu organisasi atau perusahaan. Generasi millenial merupakan anak yang memiliki bakat yang luar biasa karena mereka berkembang dalam dunia teknologi yang sudah maju. Oleh karenanya mereka akan dengan mudah bisa menyesuaikan pekerjaan yang akan mereka lakukan

Generasi millenial merupakan individu yang harus dilatih agar memiliki rasa tanggung jawab yang tinggi. Proses pengembangan rasa tanggung jawab bagi generasi millenial bisa dilakukan dengan memberikan kepercayaan kepada mereka untuk memegang suatu posisi atau pekerjaan yang menuntut mereka untuk bisa memberikan hasil yang maksimal tentang hasil dari kedudukan yang mereka pegang atau pekerjaan yang mereka lakukan.

Seorang pemimpin yang telah memberikan tanggung jawab kepada seorang generasi millenial untuk memegang suatu jabatan harus bisa memberikan contoh serta mengontrol individu itu agar tugas dan tanggung jawab yang di berikan bisa di selesaikan secara cepat dan tepat sesuai tujuan dan cita-cita yang ingin dicapai.

\section{Intention to learn}

Pembelelajaran yang intensif harus di berikan kepada generasi millenial. Karena dengan pembelajaran yang intensif (intention to learn) akan meningkatkan skill dan kemampuan bagi setiap individu. Pembelajaran yang intensif di dalam suatu lembaga atau perusahaan merupakan pelatihan yang di berikan secara teratur dan berkelanjutan demi menjaga exsistensi serta mengasah keterampilan yang dimiliki menjadi lebih baik.

Meningkatkan kemampuan diri bagi setiap individu yang tergolong kedalam generasi millenial merupakan suatu keharusan dan sangat perlu dilakukan, itu di karenakan persaingan yang terjadi di dalam dunia kerja sangat ketat dan kompetitif. Sehingga bagi generasi millenial yang tidak memiliki kemampuan di atas rata-rata akan dengan mudah tersisih dan tidak akan mampu bersaing.

Oleh karenanya pembelajaran yang intensif yang di berikan melalui pelatihan yang terstruktur dan 
berkelanjutan seperti memberikan seminar dan workshop sesuai dengan kualifikasi ilmu yang di miliki atau perkerjaan yang sedang di lakukan merupakan suatu langkah yang sangat berguna. Sehingga tujuan atau cita cita dari suatu lembaga atau perusahaan akan dengan sangat mudah tercapai, karena memiliki sumberdaya manusia yang berkualitas dan dapat di andalkan.

\section{Behavior modification}

Setiap pekerjaan yang dilakukan oleh generasi millenial dengan sangat mudah di selesaikan oleh mereka karena mereka memiliki pemahaman tentang struktur di mana mereka bekerja dan sistem yang seperti apa yang membantu mereka. Memodifikasi perilaku merupakan usaha mengubah perilaku dan emosi manusia dengan cara yang menguntungkan berdasarkan hukum-hukum teori modern proses belajar.

Modifikasi perilaku merupakan usaha untuk meningkatkan daya saing atau kemampuan bagi setiap individu. Berikut pendekatan yang bisa dilakukan untuk mencapai tujuan tersebut, yaitu sebagai berikut:

\section{Positive reinforcement}

Pendekatan yang pertama adalah positive reinforcement. ${ }^{17}$ Pendekatan ini akan memasangkan stimulus positif dengan perilaku. Teknik ini sangat umum dilakukan dengan memperkuat perilaku menggunakan system reward. Sebagai contohnya adalah ketika guru memberi reward untuk muridnya ketika mereka mendapat nilai yang bagus menggunakan stiker tertentu. Pendekatan ini juga sangat umum digunakan dalam terapi perilaku. Misalnya ketika terapis membuat sebuah perjanjian dengan klien tentang ketentuan-ketentuan reward selama menjalani terapi.

Seorang pemimpin yang sering memberikan reward $^{18}$ kepada setiap individu yang terutama generasi millenial akan memotivasi individu tersebut untuk bisa terus eksis. Karena generasi millenial adalah generasi yang sangat butuh perhargaan terhadap diri

\footnotetext{
${ }^{17}$ Santrock John W, Psikologi Pendidikan, trans. oleh Tri Wibowo BS, 6 ed. (Jakarta: Prenada Media Grup, 2015).

18 Raihani, Kepemimpinan sekolah transformatif, Cet. 1 (Yogyakarta: Penerbit \& distribusi, LKiS Yogyakarta, 2010); Ahmad Fauzi, "Kepemimpinan Kepala Madrasah Dalam Mengembangkan Lembaga Pendidikan Islam," Nidhomul Haq: Jurnal Manajemen Pendidikan Islam 2, no. 2 (6 Desember 2017): 42-53.
} 
mereka. Sehingga dengan diberikan penghargaan akan menambah kepercayaan dan eksistensi mereka untuk menjadi lebih tinggi.

\section{Negative reinforcement}

Berkebalikan dengan poin sebelumnya tentang positive reinforcement, pendekatan yang kedua adalah negative reinforcement. Pendekatan ini adalah pasangan antara perilaku tertentu dengan penghilangan stimulus yang negatif. Metode ini akan memberi 'latihan' terhadap subjek perilaku menggunakan penguat yang sifatnya negatif. Dengan penguat negatif ini, perilaku akan dicoba untuk dihilangkan.

Salah satu contoh dari negative reinforcement adalah penerapan tindakan pendisiplinan oleh supervisor untuk membuat para karyawan memastikan pekerjaannya sesuai dengan target. Dalam hal ini, tindakan pendisiplinan adalah penguat negatif dan menyelesaikan pekerjaan sesuai target adalah perilaku yang diharapkan.

\section{Punishment}

Punishment atau hukuman mungkin merupakan pendekatan yang paling umum dalam modifikasi perilaku. Hukuman biasanya dibuat bukan untuk menghilangkan perilaku tertentu, melainkan untuk memperlemahnya dengan memasangkan stimulus yang kurang menyenangkan terhadap perilaku tersebut ${ }^{19}$.

\section{Immadiate confirmation}

Strategi selajutnya adalah
immadiate confirmation yaitu suatu
keadaan di mana seseorang di tuntut untuk bisa memberikan informasi yang akurat dan benar sesuai dengan apa yang di dapat atau di dengar atau di peroleh dari lapangan. Bagaimana pun mengkonfirmasi suatu pekerjaan atau informasi yang tidak sesuai dengan kejadian yang terjadi maka akan mengakibatkan suatu kekacauan di suatu lembaga atau perusahaan. untuk

19 Muhammad Anas Ma'arif, "Hukuman (Punishment) Dalam Perspektif Pendidikan Di Pesantren," Ta'allum: Jurnal Pendidikan Islam 5, no. 1 (1 Juni 2017): 1-20, https://doi.org/10.21274/taalum.2017.5.1.120; Muhammad Anas Ma`arif, "Analisis Strategi Pendidikan Karakter Melalui Hukuman Preventif," Ta'allum: Jurnal Pendidikan Islam 6, no. 1 (6 Maret 2018): 3156,

https://doi.org/10.21274/taalum.2018.6.1.3156; Muhammad Anas Ma`arif dan Ari Kartiko, "Fenomenologi Hukuman di Pesantren : Analisis Tata Tertib Santri Pondok Pesantren Daruttaqwa Gresik," Nadwa 12, no. 1 (22 Juni 2018): 181-96, https://doi.org/10.21580/nw.2018.12.1.1862. 
itu penekanan terhadap mengkonfirmasikan suatu kebenaran harus di tanamkan kepada diri setiap individu.

Bagi generasi millenial yang hidup di era teknologi yang sedang berkembang, sehingga mengkonfirmasikan suatu kebenaran adalah suatu keharusan. Oleh karenanya sikap jujur bagi generasi millenial sangat mahal nilainya.

Konfirmasi terbagi dalam dua bentuk :

a. Bentuk Konfirmasi Positif

Bentuk konfirmasi yang menunjukan apakah ia setuju dengan informasi yang diberikan atau dicantumkan dalam permintaan konfirmasi. Bentuk konfirmasi positif menyediakan bukti hanya jika jawaban diterima oleh auditor dari penerima permintaan konfirmasi

b. Bentuk Konfirmasi Negatif

Bentuk konfirmasi negatif meminta penerimaan konfirmasi untuk memberikan jawaban hanya jika ia tidak setuju dengan informasi yang disebutkan dalam permintaan konfirmasi meskipun konfirmasi negatif yang dikembalikan dapat memberikan bukti mengenai asersi laporan keuangan.

\section{Learning practice and patterns}

Bagi generasi millenial praktek dan pola pembelajaran di tuntut lebih bervariasi. Sehingga melalui praktek dan pola pembelajaran yang bervariasi akan menghasilkan kemampuan dan kecakapan yang berkualitas. Dalam mengembangkan kemampuan diri, generasi millenial memang harus di tuntut lebih banyak melakukan praktek-praktek di lapangan untuk menghasilkan individu-individu yang unggul.

Praktek yang bisa dilakukan salah satunya adalah On the Job Training. On the Job Training (OT) atau disebut juga dengan pelatihan dengan instruksi pekerjaan sebagai suatu metode pelatihan dengan cara para pekerja atau calon pekerja ditempatkan dalam kondisi pekerjaan yang riil, di bawah bimbingan dan supervisi dari pegawai yang telah berpengalaman atau seorang supervisor.

Selanjutnya praktek yang bisa di lakukan adalah magang. Magang melibatkan pembelajaran dari pekerja yang lebih berpengalaman, dan dapat 
ditambah pada teknik Off the Job Training. Banyak pekerja keterampilan tangan, dilatih melalui program magang resmi.

\section{Manajemen Sumber Daya Manusia Di Sekolah Bagi Generasi Millenial}

Lembaga pendidikan (sekolah) adalah salah satu bidang organisasi yang menerapkan manajemen sumber daya manusia. Penerapan manajemen sumber daya manusia di bidang pendidikan bertujuan supaya bisa mencapai mvisi dan misi yang telah di tetapkan oleh istitusi tersebut secara efektif dan efisien.

\section{Rekruitmen dan Seleksi}

Kebutuhan sekolah dalam memiliki sumber daya manusia yang berkualitas agar bisa memberikan hasil yang baik bagi lembaga dalam memperoleh, mencari, dan menemukan SDM yang bermutu biasanya dilakukan dengan melakukan proses rekruitmen yang baik. Sekolah harus melakukan rekruitmen yang baik agar bisa memperoleh generasi millenial yang berkualitas. Dalam hal perekrutan dan Penyeleksian peserta didik (generasi millenial), ataupun guru yang merupakan sumber daya manusia yang mendukung perkembangan kedepannya harus bisa mencocokan keahlian yang di perlukan bagi lembaga pendidikan (sekolah) tersebut. Sekolah harus maengakses baik sumber internal maupun eksternal agar mendapatkan peserta didik yang berkualitas, ataupun guru yang handal di bidangnya. Sekolah yang memiliki guru yang handal akan dengan mudah memberikan kebutuhan yang di perlukan oleh para peserta didik (generasi millenial) sesuai dengan kemampuan yang mereka kuasai.

Guru yang teleh diterima di sekolah setelah melalui proses rekruitmen harus di training terdahulu ${ }^{20}$ untuk melihat sejauh mana ia menguasai keilmuwan yang sesuai bidangnya pada saat melamar. Sekolah menyampaikan visi dan misi sekolah yang ingin dicapai, gaji, serta kewajiban-kewajiban lain yang harus di penuhi oleh seorang guru yang telah di terima melalui proses rekruitmen.

\footnotetext{
20 Mohammad Riza Zainuddin, "Manajemen Kepala Madrasah Dalam Pengembangan Profesionalisme Guru Pendidikan Agama Islam (Pai)," Edukasi: Jurnal Pendidikan Islam 2, no. 2 (1 November 2014): 632-44, https://doi.org/10.5281/ejournal.v2i2.166; Ahmad Fauzi, "Kepemimpinan Kepala Madrasah Dalam Mengembangkan Lembaga Pendidikan Islam," Nidhomul Haq: Jurnal Manajemen Pendidikan Islam 2, no. 2 (6 Desember 2017): 42-53.
} 
Proses training ini dilakukan untuk menumbuhkan rasa tanggung jawab serta bangga terhadap bidang pekerjaan yang di jalankan oleh seorang guru. Sehingga bisa memberikan pengajaran yang maksimal kepada peserta didik.

Proses prekrutan peserta didik (generasi millenial) di sekolah harus dilakukan secara baik dan terperinci. Peserta didik sebelum diterima di training terlebih dahulu untuk melihat kemampuan masing-masing peserta didik. Tujuan training adalah agar guru bisa membagi peserta didik kedalam beberapa tinggkatan, sehingga sekolah bisa mengelompokkan mana peserta didik yang memiliki kemampuan yang tinggi, sedang, dan rendah.

Proses sekolah membagi peserta didik (generasi millenial) kedalam beberapa tinggkatan, dengan tujuan agar sekolah bisa memberikan penanganan yang tepat terhadap peserta didik tersebut sesuai kebutuhan yang mereka inginkan. sehingga lembaga (sekolah) bisa mencapai tujuan yang telah di tetapkan.

\section{Pelatihan atau Pendidikan bagi guru}

Pelatihan kepada guru yang di lakukan di sekolah adalah suatu kunci keberhasilan dalam menciptakan sekolah yang berkualitas. Pelatihan kepada guru merupakan manajemen yang baik dalam menigkatkatkan kualitas sumber daya manusia yang di miliki oleh sekolah. Dengan latihan dan pendidikan yang di lakukan oleh sekolah akan meningkatkan pengetahuan, keterampilan, dan bisa memberikan perubahan sikap yang di butuhkan oleh sekolah sehingga guru yang di berikan latihan dan pendidikan bisa lebih maju dalam menyelesaikan tugas tertentu yang di berikan kepadanya.

Dengan kemampuan guru yang meningkat, maka guru akan dengan mudah membuat proses pembelajaran dalam sistem pendidikan menjadi efektif, sehingga para siswa (generasi millenial) bisa di ajar secara maksimal sesuai dengan kebutuhan yang mereka inginkan. para murid (generasi millenial) adalah seorang anak yang memiliki sikap bebas dan fleksibel, dan juga generasi yang hidup di zaman teknologi, guru harus bisa memberikan 
apapun kebutuhan yang mereka inginkan. oleh karenanya latihan dan pendidikan yang di berikan kepada guru merupakan suatu keharusan demi meningkatkan kemampuan pengetahuan,keterampilan dan sikap sosial yang di butuhkan oleh peserta didik (generasi millenial), supaya bisa besaing di masa yang akan datang.

\section{Memberi Kebebasan Peserta Didik}

\section{Untuk Bekarya}

Sekolah harus bisa memfasilitasi kebutuhan peserta didik untuk bisa mengoptimalkan kemampuan yang dimilikinya baik dalam bidang pengetahuan maupun keterampilan. peserta didik (generasi millenial) merupakan individu yang bebas serta individu yang cepat menyesuaikan diri dengan situasi yang di alaminya. Oleh karenanya sekolah harus bisa memberikan layanan yang berkualitas demi memuaskan kebutuhan mereka.

Selain dari pada itu guru harus bisa mendampingi siswa dalam memberikan pelajaran yang dibutuhkan oleh peserta didik. Karena peserta didik (generasi millenial) adalah individu yang hidup di era teknologi maka guru di wajibkan harus menguasai teknologi dalam memberikan pelajaran kepada peserta didik. Guru harus bisa menjelaskan teknologi-teknologi yang seperti apa yang bisa mendukung mereka di masa depan, menjelaskan teknologiteknologi apa yang bisa memberikan dampak negatif bagi peserta didik di masa yang akan datan.

Peserta didik (generasi millenial) diberi kesempatan sebebasnya untuk meningkatkan kemapuan nya seperti memberikan pengalaman seperti magang, melakukan penelitian, mengikuti kompetisi baik bersifat science maupun dalam bidang olahraga. Kegiatan-kegiatan tersebut harus di berikan agar peserta didik (generasi millenial) bebas bekarya sesuai dengan kemampuan yang di kuasainya.

\section{Kesimpulan}

Strategi pengembangan manajemen sumber daya manusia bagi generasi millenial merupakan langkah langkah yang bertujuan menghasilkan individu-individu yang unggul yang memiliki kemampuan yang dapat bersaing dan memiliki nilai jual yang bisa di andalkan baik dalam suatu instansi lembaga ataupun perusahaan. 
Strategi-strategi yang di lakukan merupakan cara untuk meningkatkan kemampuan setiap individu seperti training responsibility, intention to learn, behavior modification, Immadiate confirmation, dan learning practice and patterns

Perencanaan yang baik dalam menyusun strategi-strategi guna menghasilkan sumber daya manusia yang berkualitas merupakan suatu keharusan yang menjadi tugas setiap pemimpin untuk mencapai tujuan yang telah di tetapkan. Oleh karenanya di perlukan sumber daya manusiasumber daya manusia yang handal salah satunya adalah generasi millenial. Strategi-strategi pengembangan yang telah di kemukakan diatas merupakan strategi yang bisa di gunakaan dalam rangka mengembangkan kemampuan interpersonal bagi generasi millenial.

\section{Daftar Pustaka}

Ahmad Andry, Ahmad Andry. "Lesbian, Gay, Bisexual Dan Transgender Penyembuhan Dan Upaya Membentuk Kepribadian Islami Di Era Generasi Millenial Melalui Psikoterapi Islam." FIKROTUNA 8, no. 2 (31 Desember 2018): 934-49. https://doi.org/10.32806/jf.v 8i2.3253.

Almasri, M. Nazar. "MANAJEMEN SUMBER DAYA MANUSIA: IMLEMENTASI DALAM PENDIDIKAN ISLAM." Kutubkhanah 19, no. 2 (23 Januari 2017): 133-51.

Antariksa, Walid Fajar. "Analisis Manajemen Sumber Daya Manusia Di Sekolah Dasar Islam Terpadu." Madrasab: Jurnal Pendidikan Dan Pembelajaran Dasar 10, no. 1 (29 Desember 2017): 47-56. https://doi.org/10.18860/ma drasah.v10i1.5096.

Azmy, Ahmad. "Pengembangan Kompetensi Sumber Daya Manusia untuk Mencapai Career Ready Professional di Universitas Tanri Abeng." Binus Business Review 6, no. 2 (31 Agustus 2015): 220-32. https://doi.org/10.21512/bbr. v6i2.971.

Dh, Ida Kintamani. “Analisis Sumber Daya Manusia Pendidikan Tinggi." Jurnal Pendidikan dan Kebudayaan 17, no. 4 (1 Juli 
2011):

404-18.

https://doi.org/10.24832/jpn

k.v17i4.37.

Fauzi, Ahmad. "Kepemimpinan

Kepala Madrasah Dalam

Mengembangkan Lembaga

Pendidikan Islam." Nidhomul

Haq: Jurnal Manajemen

Pendidikan Islam 2, no. 2 (6

Desember 2017): 42-53.

\begin{tabular}{|c|c|}
\hline -. "Kepemimpinar & Kepala \\
\hline Madrasah & Dalam \\
\hline Mengembangkan & Lembaga \\
\hline Pendidikan Islam." & Nidhomu \\
\hline Haq: $\quad$ Jurnal & Manajem \\
\hline Pendidikan Islam 2, & no. 2 \\
\hline
\end{tabular}

John W, Santrock. Psikologi Pendidikan.

Diterjemahkan oleh Tri

Wibowo BS. 6 ed. Jakarta:

Prenada Media Grup, 2015.

Karendra, Inggar Ariani.

"PENGARUH KUALITAS

SUMBER DAYA MANUSIA

TERHADAP

PERKEMBANGAN USAHA

PADA KPRI PERTAGUMA

KOTA

MADIUN."

EQUILIBRIUM: Jurnal Ilmiah

Ekonomi Dan Pembelajarannya 2,

no. 2 (1 Juli 2014).

https://doi.org/10.25273/equ

ilibrium.v2i2.646.

Ma arif, Muhammad Anas. "Analisis

Strategi Pendidikan Karakter

Melalui Hukuman Preventif."

Ta'allum: Jurnal Pendidikan Islam

6, no. 1 (6 Maret 2018): 31-56.

https://doi.org/10.21274/taal

um.2018.6.1.31-56.
Ma`arif, Muhammad Anas, dan Ari

Kartiko. "Fenomenologi

Hukuman di Pesantren:

Analisis Tata Tertib Santri

Pondok Pesantren Daruttaqwa

Gresik." Nadwa 12, no. 1 (22

Juni 2018): 181-96.

https://doi.org/10.21580/nw.

2018.12.1.1862.

Ma`arif, Muhammad Anas, dan

Muhammad Husnur Rofiq.

"Pola Pengembangan

Kurikulum Pendidikan

Pesantren Berkarakter: Studi

Pondok Pesantren Nurul

Ummah Mojokerto.”

TADRIS: Jurnal Pendidikan

Islam 13, no. 1 (7 September 2018): 1-16.

https://doi.org/10.19105/tipi. v13i1.1635.

Ma'arif, Muhammad Anas. "Hukuman (Punishment) Dalam Perspektif Pendidikan Di Pesantren." Ta'allum: Jurnal Pendidikan Islam 5, no. 1 (1 Juni 2017): 1-20. https://doi.org/10.21274/taal um.2017.5.1.1-20.

Mustaqim, Mustaqim. "Analisis Manajemen Pemasaran Jasa Lembaga Pendidikan Islam: Pondok Pesantren Amtsilati Darul Falah Bangsri Jepara." Nadwa 12, no. 1 (20 Juni 2018): 117. https://doi.org/10.21580/nw. 2018.12.1.2465.

Ningsih, Sri. "Perlakuan Akuntansi Sumber Daya Manusia: Assets Sekaligus Investor Bagi 
Perusahaan." Journal of Accounting and Investment 2, no. 1 (16 Desember 2015): 13-26.

Primayana, Kadek Hengki. "MANAJEMEN SUMBER DAYA MANUSIA DALAM PENINGKATAN MUTU PENDIDIKAN DI PERGURUAN TINGGI." Jurnal Penjaminan Mutu 1, no. 2 (9 Agustus 2016): 7-15. https://doi.org/10.25078/jpm .v1i2.45.

Raihani. Kepemimpinan sekolah transformatif. Cet. 1. Yogyakarta: Penerbit \& distribusi, LKiS Yogyakarta, 2010.

Rozalinda, Rozalinda. "KONSEP MANAJEMEN SUMBER DAYA MANUSIA : IMPLEMENTASI PADA INDUSTRI PERBANKAN SYARIAH." Al-Masraf: Jurnal Lembaga Keuangan dan Perbankan 1, no. 1 (1 Juni 2016): 107-24.

Sabani, Noveliyati. "GENERASI MILLENIAL DAN ABSURDITAS DEBAT KUSIR VIRTUAL." INFORMASI 48, no. 1 (25 Juli 2018): $\quad$ 95-108. https://doi.org/10.21831/info rmasi.v48i1.18078.

Setiawan, Satria Aji, dan Nova Puspitasari. "Preferensi Struktur Organisasi Bagi Generasi Millenial." Jurnal
Borneo Administrator 14, no. 2 (25 Juli 2018): 101-18. https://doi.org/10.24258/jba. v14i2.336.

Sukiati, Wiwin, dan Yuli Surya Fauzia Pertami. "ANALISIS KUALITAS SUMBER DAYA MANUSIA BAGIAN AKUNTANSI DALAM PEMAHAMAN TERHADAP LAPORAN KEUANGAN PADA BUMD KOTA BANDUNG." Jurnal Riset Akuntansi dan Keuangan 5, no. 1 (21 April 2017): 1369-76. https://doi.org/10.17509/jrak .v5i1.6738.

Tahir, M., dan Ananiah Ananiah. "Manajemen Sumber Daya Manusia Di Sekolah-Sekolah Unggulan Islam Kota Samarinda." FENOMENA 4, no. 1 (1 Juni 2012). https://doi.org/10.21093/fj.v 4i1.256.

Zainuddin, Mohammad Riza. "Manajemen Kepala Madrasah Dalam Pengembangan Profesionalisme Guru Pendidikan Agama Islam (Pai)." Edukasi: Jurnal Pendidikan Islam 2, no. 2 (1 November 2014): 632-44. https://doi.org/10.5281/ejournal.v2i2.166.

Zed, Mestika. Metode penelitian kepustakaan. Ed. 2. Jakarta: Yayasan Obor Indonesia, 2008. 